\title{
Teenagers Lifestyles at Public and Private Schools: ScreenTime and Physical Activity \\ Estilos de vida de los adolescentes en las escuelas públicas y privadas: tiempo de pantalla y actividad física \\ ${ }^{*}$ Miguel Fialho Pombeiro, **Margarida Gaspar de Matos, ${ }^{* *}$ José Alves Diniz \\ *Universidade Lusófona de Humanidades e Tecnologias (Portugal), **Universidade de Lisboa (Portugal)
}

\begin{abstract}
This study aims to compare lifestyles (LS) of students at private and public schools. All schools are from Lisbon's region (Lisbon). Five lifestyles profiles (LSP) were recognized and interpreted based on physical activity (PA) and screen time (ST). The methodology and the instruments used were adapted from the International Health Behaviour in School-aged Children (HBSC) study conducted under the auspices of the World Health Organization (WHO). Overall, the sample consists of $\mathrm{N}=2906$ students of both genders averagely aged 13.6 years (SD=1.8). The results showed that in both public and private school the access and use of technological equipment's is being democratized, but that is not true with PA practice; students of private schools are more disciplined in PA and in ST consume.
\end{abstract}

Keywords: Lifestyles Profiles, screen time, sedentary lifestyle, physical activity, public schools, private schools.

Rsumen: Este estudio tiene como objetivo comparar el estilo de vida de los estudiantes de las escuelas públicas y privadas de la región de Lisboa. Cinco perfiles de estilo de vida fueron reconocidos e interpretados teniendo en cuenta la actividad física y el tiempo de pantalla. La metodología y los instrumentos utilizados en este estudio son el resultado de una adaptación del Internacional Health Beaviour in School-aged Children en niños en edad escolar realizado bajo los auspicios de la Organización Mundial de la Salud. El estudio incluye N = 2906 estudiantes de ambos sexos, con una media de 13,6 años (SD = 1,8). Los resultados mostraron que en las escuelas públicas y privadas, hay una democratización del acceso y uso de la tecnología, pero no en la actividad física; estudiantes de colegios privados son más disciplinados en la práctica de la actividad física y el tiempo de pantalla.

Palabras clave: Estilos de vida, perfiles de tiempo de pantalla, estilo de vida sedentaria, actividad física, escuelas públicas, escuelas privadas.

\section{Introduction}

In the latest generations, there has been a rise in physical inactivity, an increased sedentary behavior (Amusa et al, 2012; WHO, 2012) as well as the adoption of a set of incorrect food habits (Juan et al., 2009), which have led to a range of health problems (heart disease, type 2 mellitus diabetes, inadequate mental condition, etc.) and to the rise in obesity which clearly stands out (Hallal et al. 2006; WHO, 2006). PA is part of the solution in all cases referred (Riskin, 2001). In Portugal, the Portuguese Technological Plan, launched in 2007, promoted the availability of mobile devices and broadband connections for free or at very low prices (Technological Plan for Education, $\mathrm{n} / \mathrm{d}$ ). As a direct or indirect result, the Portuguese youth have led the European statistics in possession of laptop computers and internet connection in the bedroom (Matos, 2008; Bridge, 2011). This situation was not followed by any assessment of its influence on lifestyle in general neither of its particular influence on PA. On one hand, the literature presents a set of inferences and associations concerning the practice of PA by Teenagers, highlighting the following: males are more active (Biddle et al, 2004; Nader et al, 2008; Pearson et al., 2009); PA decreases with age (Belanger et al, 2009; Brodersen et al, 2007); there is a direct relationship between PA as a child and, later on, that of the adult (Ministerio de Sanidad y Consumo, 2007; Telama, 2009); body image is very important for young people, (Matos et al., 2000), there is more life satisfaction among the most active (Moreno et al., 2008; Piéron, 2002) the perception of competence and weight control are seen as the major motivating factors (McCabe \& Ricciardelli, 2004); PA is very important for sleep quality (Atkinson \& Davenne, 2007; Wong et al, 2013), screen time consumption is associated with lower PA (Olds et al, 2012; Sandercock et al, 2012); teenagers higher socio-economic status is associated with more PA (Camacho, 2011; White \& McTeer, 2012), parents have a strong influence on their children's PA habits (Edwardson \& Gorely, 2010; Jago et al, 2011; Matos \& Diniz, 2005), but as children get older peers' influence overcomes the parents' (Camacho, 2011; Fitzgerald et al, 2012); the presence of parks and the freedom to leave the house influences the PA practice (Schoeppe et al, 2013); the neighborhood's social cohesion influences PA too (Carroll-Scott et al, 2013; Utter et al, 2011). On the other hand, the literature states that: young people very often organize their leisure around technological consumption; the amount of screen

Fecha recepción: 06-06-16. Fecha de aceptación: 15-11-16 Miguel Fialho Pombeiro

mfpombeiro1@gmail.com time is reaching extremely high levels (Common Sense Media 2011; Rideout et al, 2010; Salmon et al, 2011), particularly the use of screen time on the Internet (Livingstone et al. 2011; Lenhart et al, 2010; Withers \& Sheldon, 2008); multitasking has also increased greatly (Rideout et al., 2010); overweight is often associated with large consumption of screen time (Arango et al (in press); Sisson et al, 2010; Sedentary Behaviour and Obesity Expert Working Group, 2010); watching TV is still the most prevalent sedentary behavior among teenagers (Pardee et al., 2007); screen time consumption has health consequences, including a reduction in life expectancy which has already been predicted (Olshansky et al., 2005); screen time tends to increase as one gets older (Gebremariam et al, 2012; WHO, 2009); the percentage of screen time components may gradually assume different types of relevance; screen time consumption is higher in males (Granich et al, 2011; WHO, 2009); the lower the parents' qualifications and the screen time control the greater screen time consumption (Sharif \& Sargent, 2006); the existence of rules limits consumption (Granich et al, 2011; Verloigne et al, 2012); and the absence of screens in the bedroom is related with lower ST consumption (Ramirez et al 2011.); more consumption is connected to poorer academic performance (Christakis, \& Zimmerman, 2007; Sharif \& Sargent, 2006) and to less personal satisfaction (Rideout et al., 2010). In fact, there seems to be a great lack of information/ or a significant ignorance of the recommendations and rules concerning technological consumption. Many aspects of the usual lifestyle have remained, some have evolved gradually and others have evolved considerably ... The combination of sedentary and active styles is complex and varied, with the possible coexistence of large amounts of sedentary behavior and a suitable amount of PA. However, in most cases, there is in fact an antagonistic effect caused by the power that sedentary behaviors have to limit PA.

In Portugal as in many other countries, there are public schools and private schools. The Portuguese private education is paid, an average sum slightly higher than the national minimum wage. The families who prefer the private education are a small percentage of the population, who is more qualified and has a medium-high income and who willingly gives up an almost free public service in search of better education quality. In the private sector, the population, rightly or wrongly, generally considers the quality of private schools higher than that of public schools (Davies, 2004). The literature suggests that parents send their children to private schools with the goal of improving their children's academic performance (Moe, 2000).

It is important to know more about young people's lifestyles, in order to contribute to the promotion of healthy lifestyles, without 
focusing predominantly on the study of any particular sedentary behavior, but in a pluralistic perspective, with particular emphasis on the way these teenagers use the technological tools (PC, video games, TV, etc.) and practice PA. This study was always conducted with the purpose of comparing students from both public and private schools, that is, compare students who come from diverse social backgrounds.

\section{Methodology}

This study is an adaptation of the HBSC study conducted under the auspices of WHO. The participants were an extension of the Portuguese sample used in that study, but now including students from private schools in Lisbon. The international HBSC study has, as its fundamental objective, to enhance the understanding of health behaviours and wellbeing of adolescents in their social contexts, by collecting data that enables national and international comparisons (Roberts et al., 2007). This research is in its 8th edition and has the participation of 43 European and non-European countries (HBSC, 2009). In this study we chose to divide the sample into five profiles that are defined by the consumption of PA and ST, and study which variables characterize them.

\section{Sample}

The sample is made up by a convenience sample of private school students ( $\mathrm{N}=1385$ ) and public schools students ( $\mathrm{N}=1521)$ Lisbon (Portugal), consisting of $\mathrm{N}=2906$ students from the 6 th to the 12th grades, aged averagely 13.61 years $(\mathrm{SD}=1.82)$, from 10 to 20 years ( $54 \%$ male and $54 \%$ female). 53 participants were removed because their responses were considered outliers.

\section{Instrument}

The HBSC survey instrument consists of an international questionnaire that is applied every 4 years (Currie, Samdal, \& Boyce, 2001). In the private schools, this self-completion questionnaire was adapted for this research and named HBSC / WHO - Version B Private Education (VEPB). Before applying the VEPB a preliminary study was conducted to evaluate this version of the questionnaire and anthropometric measurements were carried out for all students in this study. The application of the questionnaires was undertaken during Physical Education classes. Students' participation was voluntary and anonymous.

\section{Variables}

Considering the literature review and the objectives of the study, we selected a set of variables: Personal (gender, age, school year), Sleep (sleep duration, difficulty in falling asleep), School (performance, motivation), Health (body mass index, satisfaction, self-image), Family (relationship, own room, parents and free time, financial situation, siblings), Symptoms (physical, psychological), Neighbourhood (social, physical), Computer (E\&media communications, internet at home, number of computers, online games, new relationships and internet, school performance and internet, dissatisfaction without internet, communications and internet). It is important to emphasize that the variable «age» results from the variable «year and month of birth», the variable «sleep» results from the calculation of average weekly sleep, the variable «Body mass index» results from the calculation Weight/ Height ${ }^{2}$ with classification according to the parameters of Cole and colleagues (2000). Regarding the variables «social characteristics of the neighbourhood» and "physical characteristics of the neighbourhood», as well as the variables «psychological symptoms» and «physical symptoms», we determined the Cronbach's alpha to examine the internal consistency among the items comprising each factor, yielding acceptable values for the variable «social characteristics of the neighbourhood» (Private schools á=.654 and public schools á:.612) and «physical characteristics of the neighbourhood» (Private schools á=.663 and public schools á:.608 ), as well as for the variables «physical symptoms» (Private schools á=.639 and public schools á:.654) and for the variable «psychological symptoms» (Private schools á=.611 and public schools á:.674) (Maroco, 2010).

The variables referred earlier were directly compared between public schools and private schools. These variables were also reorganized and compared in 5 LSP. More specifically «PA» was rearranged into 3 groups: «-active» (<3days/week), « \pm active» ([3,5]days/week) and «+active» (>5days/week), the variables «watch TV/DVD/video, «play computer games/console) and «use pc» were constructed through a weighted average between consumption during the week and consumption during the weekend, and «ST» resulting from the sum of the variable «watch TV/DVD/video» with «play computer games» and with «use pc», and rearrangement of the variable ST in 3 groups : «screen» (<3h/day), «tscreen» $([3,5] \mathrm{h} /$ day $)$ and «+screen» $(>5 \mathrm{~h} /$ day $)$. The LSP variable was constructed by joining the variable ST and the variable PA (days/week) organized in five profiles, more specifically: «classic» LSP1 (PA>5days/week and ST<3h/day), «moderate/mixed» LSP2 $( \pm \mathrm{PA} / \pm \mathrm{ST}$ ), «modern» LSP3 (PA $>$ 5days/week and ST $>5$ h/day), «passive» LSP4 (PA<3days/week and ST<3h/day) and «risk» LSP5 $(\mathrm{PA}<3$ days/week and $\mathrm{ST}>5 \mathrm{~h} /$ day $)$.

\section{Statistical Analysis}

The sample was divided into two groups, students from private schools and students from public schools. The results were compared. More explicitly, the two groups were compared by means of the test statistics Chi Square, ANOVA, Multivariate Regression between the 2 groups and Multivariate regression among the $5 \mathrm{LSP}$. The $\mathrm{N}$ of 5 profiles and sub profiles, the average times of PA and ST by gender and average times of PA and ST by age were also calculated.

\section{Results}

From the results, due to its size, only the following tables are presented.

\section{Discussion}

Throughout this chapter only the variables that show statistical significance between schools will be discussed.

The relationship between PA and sedentary lifestyle is not straightforward in Lisbon public and private schools

In both school types, there are students in the five profiles, but the sequence is different in each school type. The «moderate / mixed» ( \pm active/ \pm screen) LSP2 and the «risk» (-active/+screen) LSP5 hold the top positions in both school types, whereas in public schools the LSP3 comes ahead of LSP1 which is in the last position. All profiles show significant variations between private and public schools, except the «passive (-active/-screen)» LSP4. These results are as reported by Marshall et al. (2004) and Marshall et al. (2002) who, in their metaanalysis, indicate that the relationship between sedentary behavior and health is difficult to explain involving only one element of inactivity. The same results are also in agreement with Burke et al. (2006) when they refer that it is unlikely to explain inactivity as a result of an isolated generic and sedentary behavior.

In both school types there are students in «modern» profile (+active/+screen)

In Lisbon private and public schools, there are students who are both very active and who simultaneously spend a lot of time in front of the screen. It happens more frequently in public schools and there are common characteristics of this profile in both school types, which meets Nelson et al. (2005) when they report that sedentary behaviors do not necessarily limit PA practice. Granich et al. (2010), Biddle et al. (2004), Owen et al. (2000) found that sedentary behaviors often coexist and sometimes even compete with the PA practice. Such connection is higher in public schools, where there are $10.3 \%$ of students in the «modern» (+screen/ +active) LSP3 than in private schools, where the 


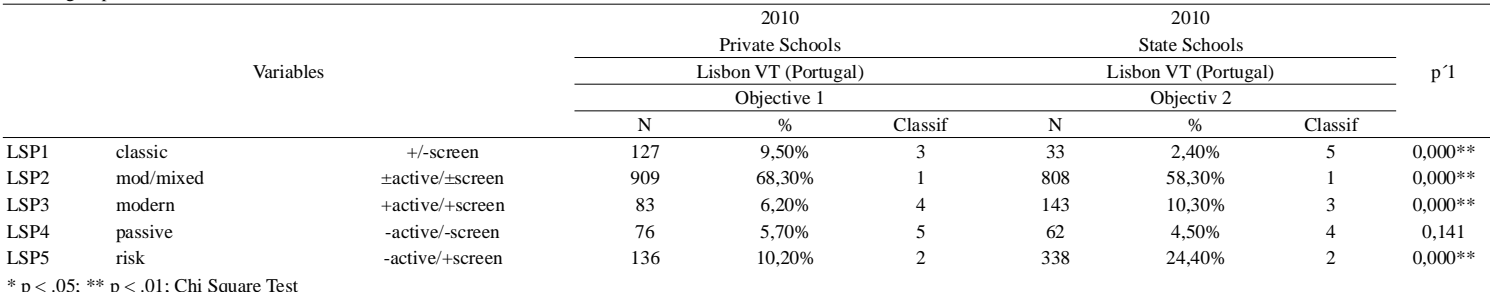

Table 2:

$\mathrm{PA}$ and ST in

\begin{tabular}{|c|c|c|c|c|c|c|c|c|c|c|c|c|c|c|c|}
\hline & \multirow[t]{2}{*}{ Variables } & \multicolumn{3}{|c|}{$\begin{array}{c}\text { LSP1 } \\
\text { classic }\end{array}$} & \multicolumn{3}{|c|}{$\begin{array}{c}\text { LSP2 } \\
\text { moderate/mixed } \\
\text { 士active/ } \pm \text { screen }\end{array}$} & \multicolumn{3}{|c|}{$\begin{array}{c}\text { LSP3 } \\
\text { modern }\end{array}$} & \multicolumn{5}{|c|}{$\begin{array}{c}\text { LSP4 } \\
\text { passive }\end{array}$} \\
\hline & & Average & SD & $\%$ & Average & \pm active/ \pm screen & $\%$ & Average & SD & $\%$ & \multicolumn{5}{|c|}{-active/-screen } \\
\hline \multirow{5}{*}{ Private Schools } & $\begin{array}{l}\text { Physical Activity (days } \\
\text { per week) }\end{array}$ & 6,6 & 0,49 & & 3,92 & 1,3 & & 6,48 & 0,5 & & 1,5 & 0,72 & & 0,68 & \\
\hline & WatchTV/DVD/video & 0,85 & 0,47 & $48,60 \%$ & 1,96 & 1,2 & $44,90 \%$ & 3,03 & 1,41 & $40,20 \%$ & 0,97 & 0,53 & $54,0 \%$ & 1,54 & $40,0 \%$ \\
\hline & $\begin{array}{l}\text { Play computer games (or } \\
\text { console) }\end{array}$ & 0,36 & 0,38 & $20,60 \%$ & 1,05 & 1,16 & $24,0 \%$ & 1,95 & 1,39 & $25,9 \%$ & 0,24 & 0,32 & $13,40 \%$ & 1,76 & $24,50 \%$ \\
\hline & Use the computer & 0,54 & 0,44 & $30,90 \%$ & 1,36 & 1,17 & $31,10 \%$ & 2,56 & 1,35 & $34,0 \%$ & 0,58 & 0,38 & $32,40 \%$ & 1,61 & $35,50 \%$ \\
\hline & Screen Time & 1,75 & 0,73 & & 4,33 & 2,5 & & 7,53 & 2,41 & & 1,79 & 0,68 & & 2,5 & \\
\hline \multirow{5}{*}{ State Schools } & $\begin{array}{l}\text { Physical Activity (days } \\
\text { per week) }\end{array}$ & 6,82 & 0,39 & & 3,73 & 1,28 & & 6,68 & 0,47 & & 1,58 & 0,67 & & 0,66 & \\
\hline & WatchTV/DVD/video & 1,02 & 0,54 & $56,9 \%$ & 2,85 & 1,52 & $42,90 \%$ & 3,39 & 1,66 & $37,9 \%$ & 0,94 & 0,69 & $48,7 \%$ & 1,67 & $42,1 \%$ \\
\hline & $\begin{array}{l}\text { Play computer games (or } \\
\text { console) }\end{array}$ & 0,29 & 0,27 & $16,2 \%$ & 1,65 & 1,63 & $24,8 \%$ & 2,73 & 1,75 & $30,5 \%$ & 0,37 & 0,49 & $19,1 \%$ & 1,57 & $22,9 \%$ \\
\hline & Use the computer & 0,48 & 0,38 & $26,8 \%$ & 2,14 & 1,67 & $32,20 \%$ & 2,82 & 1,64 & $31,5 \%$ & 0,62 & 0,54 & $32,1 \%$ & 1,73 & $34,8 \%$ \\
\hline & Screen Time & 1,79 & 0,59 & & 6,39 & 3,32 & & 8,94 & 3,08 & & 1,93 & 0,75 & & 2,8 & \\
\hline
\end{tabular}

number of students in the «modern» (+screen/ +active) LSP3 is 6.2\%.

This profile is characterized at both schools by:

- Having more male students, specifically in private schools the «male» gender is 2.5 times more likely to be LSP3 (OR=0.4; 95\% CI:[0.2-0.9], $\mathrm{p}<.05)$ and in public schools the «male» gender is 5 times more likely (OR=0.2; CI:[0.1-0.4], $\mathrm{p}<.05$ ) to be LSP3.

- Being less frequent than «risk» (-active /+screen) LSP5, more particularly in private schools where the number of LSP3 students is almost twice more than that in public schools where there are nearly 2.5 times more «risk» (-active/+screen) LSP5 students than «modern» (+active/+screen) LSP3.

- Being the profile with more computers.

- Having students who feel happier with the physical characteristics of their neighborhood.

- Being the profile that communicates with more E\&media friends on a daily basis.

- Being the profile that mostly drops school performance due to time spent on the internet.

- Having students who depend more time on the internet than in any other «+screen» profile, i.e., within the «+screen» profiles, the «modern» (+active /+screen) LSP3 is the «+active» one and students have greater need to use the internet in order to make their life less boring, empty or joyless.

- Being the profile who most often plays «computer games (or console).»

The ST has the potential to replace PAboth in private schools and in public schools in Lisbon

If one takes into account the notion that it is possible to have sedentary behaviors and simultaneously be active both in private schools and in public schools in Lisbon, as it is stated above, then it can be inferred that ST has the potential to replace PA. Although there is a «modern» (+active/+screen) LSP3, i.e., it is possible to have sedentary behaviors and simultaneously be active, the ST may have implications for the PA. Notice that in both private and public schools, in the «+ active» profiles (BP> 5 days / week) the average of PA practice is lower in «+screen» profile (ST $>5 \mathrm{~h} /$ day) than in «-Screen» profile $(\mathrm{ST}<3 \mathrm{~h} /$ day), suggesting that a greater ST, even for the most active students, may decrease the PA time, more distinctly in public schools. That is also mentioned by Marshall et al. (2002) when they public that sedentary behaviors limit PA practice.

PA practice habits are insufficient both in public and in private schools

In the Lisbon public and private schools, PA is insufficient, in public schools it is 3.55 days/week ( $\mathrm{SD}=1.95$ ) and in private schools it is 3.95 days/week ( $\mathrm{SD}=1.85$ ), that is, in both school types PA, takes less than 4 days/week. Thus, the recommendations of $1 \mathrm{~h}$ daily practice for students aged from 6 to 17 years or more, with moderate-to-vigorous intensity (USDHHS, 2008), are not complied with. Portugal has one of the lowest rates of frequency of PA practice if compared to 35 other countries, Matos \& Diniz (2007). Moreover, the Euro Barometer (2010) states that Portugal is the European country where more youngsters refer never having practiced PA. In the total amount of samples from private and public schools, $80.4 \%$ of students are not «+active» $(>5$ days/week of PA) and 31\% are actually «-active» ( $<3$ days/week of PA), which is a better rate than that referred to in Matos \& Equipa Aventura Social e Saude (2010), obtained within the Portuguese population (public schools) of whom $86 \%$ did not perform PA every day. However, this rate is even worse than that expressed by the results from the US Centers for Disease Control and Prevention (2010) who claim that only $68 \%$ of US young people did not perform the necessary PA according to the recommendations to promote health.

Lisbon public schools have more "+screen» students and private schools in Lisbon have more "-screen» students, the screen time is higher in public schools and the sequence in the screen time composition is the same in both school types

Lisbon public schools (66.7\%) have more 31.8\% «+screen» students ( $>$ 5hours/day) than Lisbon private schools (34.9\%) and private schools (33, 5\%) have more 22\% «-screen» students ( $<3 \mathrm{~h} /$ day) than public schools (11.5\%). The total samples of Lisbon private and public schools, show that there are $51 \%$ of students who are «+screen» (ST $>5 \mathrm{~h} /$ day) and $22.3 \%$ who are «-screen» (ST $<3 \mathrm{~h} /$ day). There is a great average 
consumption of ST in both school types. What is observed is that in public schools, the average ST is $6: 58 \mathrm{~h}$ which is $2: 27 \mathrm{~h} \mathrm{higher} \mathrm{than} \mathrm{that}$ in private schools which have $4: 31 \mathrm{~h} \mathrm{ST}$. Both figures are lower than the 7:11h in Rideout et al. (2010). In both school types and in all profiles the predominant consumption is «watching TV/DVD/video» followed by «using the computer» and «playing computer games (or console) which meets Rideout et al. (2010) who reported that watching TV remains the main technological consumption. More precisely, public schools consume (3: 04h) whereas private schools consume (2h). The result is that public schools consume 1:04h plus «watching TV/DVD/ video» daily; both rates are lower than the 4:29h in the US of Rideout et al (2010). Regarding consumption of «playing computer games (or console)», the public schools' consume is (1: $53 \mathrm{~h})$ while the private schools' consume is (1:06h). So, public schools consume $0: 47 \mathrm{~h}$ plus, on a daily basis. Such rates are respectively above and below those mentioned by Rideout et al (2010) 1: 30h. In what concerns «using the computer», the public schools' consume is (2: 26h) while private schools' consume is $(1: 29 \mathrm{~h})$. Therefore, public schools consume daily $0: 57 \mathrm{~h}$ plus «using the computer «. Both rates are superior to 1:12h, Rideout et al. (2010).

\section{In both school types PA habits and screen time tend to stay}

In Lisbon public and private schools, the be active behavior and proper screen consumption stay constant as one gets older. That is, the «healthy» (+active/-screen) LSP1 remains stable for life. It means that either in private schools or in public schools, more specifically the practice of PA, as well as the recommended proportions of screen consumption can become a habit, that once acquired, remains constant after the regular 13 years in public schools and it remains permanent in private schools. This suggests that PA and ST habits remain after acquired, and it is in accordance with Kirk (2005) on the importance of these habits being acquired at earlier ages, and with Kjonniksen et al. (2008) who report a higher probability of practicing PA in adulthood for those who did it when they were young. Telama (2009) also refers to the tracking of PA from childhood to adulthood. Other authors have also reported that sedentary behaviors in childhood are very harmful to one's health and they tend to be stable over time, remaining unchanged in adulthood (Biddle et al, 2009; Nelson et al., 2005; Sundblad et al, 2008).

Students from private schools in Lisbon follow the rules concerning screen time and PA more efficiently

Students from Lisbon private schools seem to follow the PA and STrecommendations more efficiently, that is, in private schools (9.54\%) there are about 3 times more students in «classic» (+active/-screen) LSP1 than in Lisbon public schools (3\%). On the other hand, in public schools (24\%) the number of students in «risk» (-active/+screen) LSP5 is more than twice higher than that in private schools (10.2\%). Moreover, it was found that students in public education are 2.2 times more likely to belong to (risk) «-active / +screen» LSP5 (OR=2.2; 95\% CI:[1.53,1]; $\mathrm{p}<.01$ ). Additionally, students in private education are 5 times more likely to belong to (healthy) «+active/-screen» LSP1 (OR=0.2; 95\% CI:[0.1- 0.5], p<.01). In an international study (Pombeiro, 2015), the same private schools line up with the countries who have the highest financial level, the 39 countries belonging to the International HBSC study (Currie et al., 2012), who display lower ST consumption, specifically less consumption of « watch TV/DVD/video or playing computer games (or console)». There is possibly a greater concern with PApractice in private schools, as well as the existence of ST consumption rules that limit the consumption of ST(Granich et al, 2011; Verloigne et al, 2012).

In both school types, PA decreases up to the entry into adulthood In Lisbon public and private schools, students reach the age of 17 with an average PA that is below what it used to be at the age of 11 . and this reduction is greater in private schools (-1.25 days/week) than in public schools (-0.33 days/week). This result is consistent with what was reported by Biddle et al. (2004), Kjonniksen et al. (2008) and $\mathrm{WHO}$ (2009). In what concerns gender matters, in public schools, there is a higher reduction of PA practice at the age of 17 in the female gender (-0.78 days/week) than in themale gender(-0.17 days/week), if compared to the age of 11 . On the contrary, in private schools, there is a greater reduction of PA practice at the age of 17 in the male gender (-1.47 days/ week) than in the female gender (- -0.84 days/week), if compared to the age of 11 . These results are in agreement with Calmeiro \& Matos (2004) and Nelson et al. (2006) for public schools but not for private schools. On the other hand, the values of PA at the age of 17 are, on average, lower in the private schools (3.21 days/week) than in the public schools (3,61 days/week), and between genders, the values in the female one are greater in the private schools (3.17 days/week) than in the public schools (2.81 days/week), but lower in the male gender (4.12 days/week) in the public schools than in the private ones (3.24 days/ week). In short, the PA practice decreases up to adulthood in Lisbon both public and private schools and this decrease is greater in private schools. Concerning gender, the decrease is higher in public schools for the female gender and in private schools the reduction is higher for the male one. The value of PA is even inferior in the private schools if compared to the public schools after the age of 17 in the male gender, although the average for PAat all ages is higher in private schools. These data are certainly not good indicators. Matos \& Aventura Social e Saude (2004) and Kirk (2005) report associations between PA in childhood and its practice into adulthood.

The screen time increases until the early adulthood in both school types especially in public schools and differently between genders

In public and private schools, students reach the age of 17 with an ST average higher than what they used to have at the age of 11 . Such ST increase is higher in public schools ( $+0: 50 \mathrm{~h})$ than in private $(+0: 40 \mathrm{~h})$. Both cases are in agreement with the studies published by Biddle et al. (2009), Gebremariam et al. (2012), Olds et al. (2006) and Olds et al. (2009) who reported that ST increases with age. In what concerns gender, in both school types, there is a greater increase in ST consumption in the female gender, i.e., at the age of 17 the female gender has $0: 55 \mathrm{~h}$ plus ST in public schools and 0:52h plus ST in private schools, and the male gender 0:43h plus ST in public schools and 0:38h plus ST in private schools, if compared to the ST at the age of 11 . In other words, ST consumption increases until adulthood in both public and private schools in Lisbon. Such increase is greater in public schools. These are worrying results according to Ministerio de Sanidad y Consumo (2007) where it is said that sedentary teens today are likely to be the inactive adults of the future.

\section{There is greater PA in the male gender in both school types}

In Lisbon private and public schools, when comparing genders, PA practice is higher in the male gender than in the female and this difference is bigger in public schools, with 1 day / week plus, than in private schools, with 0.98 days/week plus. Moreover, in both school types, the female gender is more likely to belong to «-active» profiles. Notice that in private schools the female gender is 4 times more likely to belong to LSP4 (OR=4.2; 95\% CI:[1.8-9.8], $\mathrm{p}<.01$ ) and is 2.6 times more likely to belong to LSP5(OR=2.6; 95\% CI:[1.4-5.0], $\mathrm{p}<.01$ ). In public schools, the female gender is 21 times more likely to belong to LSP4 $(\mathrm{OR}=20.9,95 \% \mathrm{CI}:[1,2-359.4], \mathrm{p}<.01)$ and is twice more likely to belong to the LSP5(OR=2.0; 95\% CI:[1.2-3.3], $\mathrm{p}<.05)$. That is, in both school types, what happens is what the authors Nader et al. (2008) and Troiano et al. (2008) stated when they referred that the PA practice is lower in the female gender.

In both schools, the male gender consumes more screen time, especially in public schools, largely due to increased consumption of playing computer games (or console)

The male gender consumes more ST than the female one in Lisbon public and private schools. This difference is higher in public schools, (+0:46h), than in private schools, $(+0: 34 \mathrm{~h})$, which meets what other 
authors, such as Booth et al. (2006), Olds et al. (2009) and Salmon, et al. (2004). The male gender consumes as much «watch TV/DVD/video» as the female one in both public and private schools. The male gender consumes slightly more «using the computer» than the female one in the public schools, with $0: 01 \mathrm{~h}$ plus. This result is according to the study HBSC 2006 (WHO, 2009), but in private schools the male gender consumes less $0: 10 \mathrm{~h}$. In what concerns the «computer games (or console)» the male gender consumes more than the female one in public and private schools. This difference is higher in public schools, $(+1: 06 h)$, than in private schools $(0: 52 \mathrm{~h})$, which meets what Rideout et al. (2010) report when they refer that the male gender consumes more than the female one. To summarize, in both public and private schools, the male gender has more ST, largely as a result of higher consumption of «playing computer games (or console).»

The school performance should have different interventions according to the type of school

Academic achievement stands out of the exclusive results of Lisbon public and private schools presented above. In private schools, the «+active» profiles have the best academic performance. However, in the public schools, the «-screen» profiles have better academic performance. The private schools results are according to the study described in Active Healthy Kids Canada (2012), where the existence of an association between more PAand better school performance is referred. On the other hand, public schools are in line with Sharif \& Sargent (2006) where an association between more ST and worse school performance is referred to. Thus, an intervention to improve school failure in private education should fight the «-active» behaviors and public education should fight the «+screen» behaviors.

Parents' deeper knowledge about their children's free time in Lisbon private schools

The results of the analysis of Lisbon public and private schools students' unique characteristics presented previously also show parental relationship with the children's free time. It is noticed that in private schools (54.7\%) more parents know a lot about their children's free time than in public schools (51.7\%). On the other hand, in private schools it is in «-screen» profiles where there are more parents who know a lot about their children's free time. The same doesn't happen in public schools, which may mean that there is concern and influence in order to make students become " -screen», which is in line with what Edwardson \& Gorely (2010) report when they point out that parents have a strong influence on their children's PA and with what Sharif \& Sargent (2006) report about lower ST during the week being associated with greater parental supervision. Most public schools researched in this study have «fragmented» timetables. If such situation is related with the fact that there is less parental knowledge about children's free time and that there is not any greater knowledge about the «-screen» profiles, one may draw the conclusion that parental knowledge about children's free time is not such an important concern and it may lead to increased screen consumption.

Between public and private schools the ratio of students who have access to the Internet is higher in Lisbon public schools

With regard to the Internet, it is emphasized that in Lisbon public schools:

- Students communicate more with E\&media friends. There are $59.6 \%$ public school students who very often communicate with E\&media friends, whereas in private schools the number is $54.4 \%$.

- The internet impairs school performance more seriously. Notice that, in public schools, $13.9 \%$ of students often drop their school performance results due to time spent on the internet and in private schools the number is $2.5 \%$. More specifically, students who rarely drop their school performance due to time spent on the Internet are more likely to belong to private schools (OR=0.4; 95\% CI:[0.2-0.7], $\mathrm{p}<.01)$.

- Students play online more, in public schools $24.3 \%$ of the students play online very often and $16.8 \%$ of the students in private schools do the same.

- Relationships are created over the Internet. It was found that, in public schools, $16.4 \%$ of students «often» create relationships on the Internet and in private schools the number is $4.1 \%$. More specifically, students who «rarely» create «new relationships» on the Internet are more likely to belong to private schools (OR=0.3; 95\% CI: [0.2-0.5], $\mathrm{p}<.01)$ or $(\mathrm{OR}=0.4 ; 95 \%$ : [0.2-0.6], $\mathrm{p}<.01)$.

- There is much greater dissatisfaction when the students don't have internet. Notice that, in public schools, $32.6 \%$ of students are «often» dissatisfied and $13.1 \%$ in private schools feel the same. More specifically, students who «rarely» feel unhappy when there's no Internet are more likely to belong to private schools (OR=0.4; 95\% CI: [0.30.6], $\mathrm{p}<.01)$ and (OR=0.4; 95\% CI:[0.3-0.6], $\mathrm{p}<.01)$.

- One communicates more often through the Internet. In public schools, $46.9 \%$ of the students often communicate over the Internet and in private schools the number is $24.5 \%$. More specifically, students who «every day or more than once a day» communicate over the Internet are less likely (50\%) to belong to private schools than to public schools (OR=0.5; 95\% CI:[0.3-0.5 ]; $\mathrm{p}<.01$ ).

- In both school types, further access to technology relates to more consumption. Notice that, in public and private schools, it is in the «+screen» profiles where there is greater amount of computers at home and it is where there are more students with access to the internet at home.

There is a democratization of the access to the IT and to technological consumption, but not to PA

In both school types, students are very well equipped in technological terms; in fact, there's a slightly greater amount of «having computer at home» in private education students (99.6\%) if compared to the public schools students (98.6\%), although there a is greater number of computers (two or more) in the private school students' home (90\%) than in the public school students' (78.5\%). As for the internet access, in private schools, with $98.9 \%$ access, there are more students with internet at home than in public schools with $95 \%$ access. However, both have very high rates of home Internet. In both school types the rates are higher than those found by Rideout et al. (2010) referring to the US rates in 2009 with 93\% and 84\% PC with internet. And the rates are still much higher than those described by Bringué \& Sádaba (2008) in Argentina, Brazil, Chile, Colombia, Peru and Mexico who report the existence of $65 \%$ homes with PC and $46 \%$ with internet. Such massive use of the PC was not only a consequence of the technological evolution itself, but it was also enhanced by the Portuguese government policies (Technological Plan for Education, $\mathrm{n} / \mathrm{d}$ ) put into practice through the e.escolas programs, among other measures, which promoted the democratization of the portable PC and the Internet in Portugal. On the other hand, it turns out that both in public and in private schools in Lisbon the «+screen» profiles students are not in better financial terms. That is, there is a democratization of access to technology in both school types. With regard to the PA, it is emphasized that in both school types there are more students from families with higher financial incomes in the "+ active» profile. It is also verified, in both school types, that within the two «+screen» profiles there are high financial income students in «modern» (+active/+screen) LSP3, which means that high income students are in the +active» profile. Private schools in Lisbon practice more PA than public schools, specifically private schools with 3.95 days/week, $\mathrm{SD}=1.85$, have a PA practice average (60 minutes/day) which is 0.40 days/week higher than that of public schools with 3.55 days/week, $\mathrm{SD}=1.95$. In short, the PA practice continues to be associated with higher financial income families, which is according to Walter et al. (2009) and White \& McTeer (2012), but in what concerns ST there seems to have been a democratization that led to its massive use, which matches Common Sense Media(2011), Fletcher et al. (2013) and Hoyos \& Jago (2010) when they refer the connection between higher ST and lower financial income. 


\section{Conclusions}

One can summarily characterize Lisbon Private Schools, as being attended by a higher financial level population and as being associated with a better set of characteristics for their students. In both private and public schools, there is a democratization of access to technological tools and to technological consumption, but not to PA. It is common for the screen time to have the potential to replace PA. Students from private schools are more rules abiding regarding PArecommendations and even more rules abiding on the topic of screen timerecommendations. In what concerns the relationship between PAand screen time, as well as the strategies to improve school performance, the targets should be different according to the school type. Are the issues that dictate success or failure at school in Lisbon (Portugal) more intrinsic of the population, or rather, are they matters of education and social habits ...?

\section{References}

Active Healthy Kids Canada (2012). Is active playextinct? The active healthy kids canada 2012. Report card on physical activity for children and youth. Toronto: Active Healthy Kids Canada.

Amusa, L, Toriola, A., \& Goon, D. (2012). Youth, physical activity and leisure education: Need for a paradigma shif. African Journal for Physical, Health Education, Recreation and Dance, 18, (4:2), 992-1006.

Arango, C., Parra, D., Gómez, L., Lema, L., Lobelo, F., \& Ekelund, U. (in press). Screen time, cardiorespiratory fitness and adiposity among school-age children from Monteria, Colombia. Journal of Science and Medicine in Sport. Retrieved from www.sciencedirect.com/science/journal/aip/14402440.

Atkinson, G., \& Davenne, D. (2007). Relationships between sleep, physical activity and human health. Physiology Behavior, 90, 229-235. DOI: 10.1016 j.physbeh.2006.09.015

Belanger, M., Gray-Donald, K., O’Loughlin, J., Paradis, G, \& Hanley, J. (2009) When adolescents drop the ball: Sustainability of physical activity in youth. American Journal of Preventive Medicine, 37(1), 41-49. DOI: 10.1016/ j.amepre.2009.04.002

Belanger, M., Gray-Donald, K., O’Loughlin, J., Paradis, G, Hutcheon, J., Maximova, K., \& Hanley, J. (2009). Paticipation in organised sports does not slow declines in physical activity during adolescence. International Journal of Behavioral Nutrition and Physical Activity, 61(1), 22.

Biddle, S., Gorely, T., \& Marshall, S. (2009). Is television viewing a suitable marker of sedentary behavior in young people? Annals of Behavioral Medicine, 38,147-153. DOI: 10.1007/s12160-009-9136-1

Biddle, S., Gorely, T., Marshall, S., \& Cameron, N. (2009). The prevalence of sedentary behavior and physical activity in leisure time: A study of Scottish adolescents using ecological momentary assessment. Preventive Medicine, 48(2), 151-155. DOI: 10.1016/j.ypmed.2008.10.025

Biddle, S., Gorely, T., \& Stensel, D. (2004). Health-enhancing physical activity and sedentary behaviour in children and adolescents. Journal of Sports Sciences, 22(8), 679-701.DOI:10.1080/02640410410001712412

Biddle, S., Marshall, S., Gorely, T., \& Cameron, N. (2009). Temporal and environmental patters of sedentary and active behaviors during adolescents. Leisure Time International Journal of Behavioral Medicine, 16(3), 278-286. DOI: 10.1007/s12529-008-9028-y

Biddle, S., Pearson, N., Ross, M., \& Braithwaite, R. (2009). Traking of sedentary behaviours of young people: Asystematic review. Preventive Medicine, 51,345351. DOI: 10.1016/j.ypmed.2010.07.018

Booth, M., Okely, A., Denney-Wilson, E., Hardy, L., Yang, B., \& Dobbins, T. (2006). NSW schools physical activity and nutrition survey (SPANS) 2004: summary report. Sydney, Australia: Department of Health.

Bringué, X., \& Sádaba, C. (2008). La geración interactiva en iberoamerica. Niños y adolescentes ante las pantallas. Barcelona: Editorial Ariel, SA.

Brodersen, N., Steptoe A., Boniface, D., \& Jane, W. (2007). Trends in physical activity and sedentary behaviour in adolescence: ethnic and socioeconomic differences. British Journal of Sports Medicine, 41, 140-144. DOI:10.1136/ bjsm.2006.031138

Burke, V., Beilin, L., Durkin, K., Stritzke, W., Houghton, S., \& Cameron, C. (2006). Television, computer use, phycal activity, diet and fatness in Australian adolescents. International Journal of Pediatric Obesity, 1, 248-255. DOI: 10.1080/17477160600984975

Calmeiro, L. \& Matos, M. (2004). Psicologia do exercício e da saúde. Lisboa: Visão e Contextos.

Camacho, I. (2011). A influência da familia na saude e nos comportamentos de risco nos adolescentes portugueses. (Tese de Doutoraemento não publicada). Lisboa: FMH.
Carroll-Scott, A., Gilstad-Hayden, K., Rosenthal, L., Peters, S., McCaslin, C., Joyce, R., \& Ickovics, J. (2013). Disentangling neighborhood contextual associations with child body mass index, diet, and physical activity: The role of built, socioeconomic, and social environments. Social Science \& Medicine, 95, 106-114. DOI: 10.1016/j.socscimed.2013.04.003

Castells, M. (1996). The Rise of the Network Society. Oxford: Blackwell.

Centers for Disease Control and Prevention(2010). Youth riskbehavior surveillanceUnited States, 2009. Surveillance Summaries MMWR, 59(5), 1-142.

Christakis, D., \&Zimmerman, F. (2007). Violent television viewing during preschool is associated with antisocial behavior during school age. Pediatrics, 120(5), 993-999. DOI: 10.1542/peds.2006-3244

Common Sense Media (2011). Zero to eight: Children's media use in America. A Common sense media research study. Retrieved from http:// www.commonsensemedia.org/sites/default/files/research/zerotoeightfinal2011.pdf

Currie, C., Samdal, O., \& Boyce, W. (2001). HBSC, a WHO cross national study: Research protocol for the 2001/2002 survey. Copenhagen: WHO.

Davies, S. (2004). School choice by default? Understanding the demand for private tutoring in Canada. American Journal of Education, 110, 233-255. DOI: 10.1086/383073

Edwardson, C., \& Gorely, T. (2010). Parental influences on different types and intensities of physical activity in youth: A systematic review. Psychology of Sport \& Exercise, 11, 522-535. DOI: 10.1016/j.psychsport.2010.05.001

Eurobarometer (2010). Sport and physical activity. Retrevied from http://ec.europa.eu/ public_opinion/archives/ebs/ebs_334_en.pdf

Fitzgerald,A., Fitzgerald, N., \& Cian Aherne, C. (2012). Do peers matter? Areview of peer and/or friends'influence on physical activity amongAmerican adolescentes. Journal of Adolescence, 35, 941-958. DOI:10.1016/j.adolescence

Fletcher, E., Whitaker, R., Marino,A., \& Anderson, S. (2013). Screen time at home and school among low-income children attending head start. Child Indicators Research. DOI 10.1007/s12187-013-9212-8.

Gebremariam, M., Totland, T., Andersen, L., Bergh, I., Bjelland, M., Grydeland, M.,....Lien, N. (2012). Stability and change in screen-based sedentarybehaviours and associated factors among Norwegian children in the transition between childhood and adolescence. BMC Public Health, 12, 104. DOI: 10.1186/ 1471-2458-12-104

Granich, J., Rosenberg, M., Knuiman, M., \& Timperio, A. (2010). Understanding children's sedentarybehaviour:Aqualitativestudy of the familyhomeenvironment. Health Education Research, 25(2), 199-210. DOI: 10.1093/her/cyn025

Granich, J., Rosenberg, M., Knuiman, M., \& Timperio, A. (2011). Individual, social and physical environment factors associated with electronic media use among children: Sedentary behavior at home. Journal of Physical Activity and Health, 8, 613-625.

Hallal, P., Victora, C., Azevedo, M., \& Wells, J. (2006). Adolescent physical activity and health:A systematic review. Sports Medicine, 36(12), 1019-1030. DOI:10.2165/00007256-200636120-00003

Hoyos, C., \& Jago, R. (2010). Systematic review of correlates of screen-viewing among young children. Preventive Medicine, 51, 3-10. DOI: 10.1016/ j.ypmed.2010.04.012

Jago, R., Davison, K., Brockman, R., Page, A., Thompson, J., \& Fox, K. (2011). Parenting styles, parenting practices, and physical activity in 10- to 11-year olds. Preventive Medicine, 52, 44-47.DOI: 10.1016/j.ypmed.2010.11.001

Juan, F., Montes, M. \& Piéron, M. (2009). Actividad Física y estilos de vida saludables. Análisis de los determinantes de la prática en adultos. Almeria: Wanceulen Editorial Desportiva, S. L.

Kirk, D. (2005). Physical education, youth sport and lifelong participacion: The importance of early learning experiences. European Physical Education Review, 11(3), 239-225. DOI: 10.1177/1356336X05056649

Kjonniksen, L., Torsheim, T., \& Wold, B. (2008). Tracking of leisuretime physical activity during adolescence and young adulthood:A10-year longitudinal study. International Journal of Behavioral Nutrition and Physical Activity, 5(1), (69). DOI: 10.1186/1479-5868-5-69

Lenhart, A., Purcell, K., Smith, A., \& Zickuhr, L. (2010). Social media and young adults. Pew Internet \& American Life Project. Retrieved from http:// pewinternet.org/Reports/2010/Social-Media-and-Young-Adults.aspx

Livingstone, S., Haddon, L., Gorzig, A., \& Olafsson, K. (2011). Risk and safety on the internet. The perspective of European children. Final findings from the EU Kids online survey of 9-16 year olds and their parents. London, LSE.

Marshall, S., Biddle, S., Gorely, T., Cameron, N., \& Murdey, I. (2004). Relationships between media use, body fatness and physical activity in children and youth:A meta-analysis. International Journal of Obesity, 28, 1238-1246. DOI: 10.1038/ sj.ijo.0802706

Marshall, S., Biddle, S., Sallis, J., McKenzie, T. \& Conway, L. (2002). Clustering of sedentary behaviours and physical activity among youth: Across-national study. Pediatric Exercise Science, 14, 401-417.

Matos, A. (2008). Ver TV em família. Comunicar: Revista Cientifica de Educomunicação, n³1, XVI, 121-127. 
Matos, M., \& Diniz, J. (2005). Portuguese adolescents: Active lifestyles and health. In Diniz, J. A., Costa, F. C., Onofre, M., AIESEP 2005 World Congress. Active Lifestyles: The impact of Education and Sport (57-68). Cruz Quebrada: FMH.

Matos, M., \& Equipa Aventura Social e Saúde (2004). Risco e protecção. Lisboa: FMH.

Matos, M. \& Equipa Aventura Social e Saúde (2010). A saúde dos adolescentes portugueses. Relatório preliminar do estudo HBSC 2010.

Matos, M., Simões, C., Carvalhosa, S., Reis, C., \& Canha, L. (2000). A saúde dos adolescentes portugueses. Estudo nacional da rede europeia HBSC/OMS 1998. Lisboa: FMH/PEPT- Saúde.

McCabe, M., \& Ricciardelli, L. (2004). A longitudinal study of pubertal timing and extreme body change behaviors among adolescent boys and girls. Adolescence, 39(153), 145-166.

Ministerio de Sanidad y Consumo (2007). Encuesta nacional de salud de España 2006. Instituto Nacional de Estadística. Madrid. Retrieved from http:// www.msc.es/estadEstudios/estadisticas/encuestaNacional/encuestaNac2006/ EstilosVidaPorcentaje.pdfSedentary Behaviour and Obesity in a Large Cohort of Children

Moe, T. (2000). Theattraction of private school. Retrieved from http:// www.educationnext.org/unabridged/2001sp/moe.html

Moreno, J., Cervelló, E., \& Moreno, R. (2008). Importancia de la práctica físicodeportiva y del género en el autoconcepto físico de los 9 a los 23 anos. International Journal of Clinical and Health Psychology, 8(1), 171-183.

Nader, P., Bradley, R., Houts, R., McRitchie, S., \& O’Brien, M. (2008). Moderateto-vigorous physical activity from ages 9 to 15 years. JAMA, 300(3), 295-305 DOI: 10.1001/jama.300.3.295

Nelson, M., Gordon-Larsen, P., Adair, L., \& Popkin, B. (2005). Adolescent physical activity and sedentary behavior: Patterning and long-termmaintenance.American Journal Preventive Medicine, 28, 259-266. DOI: 10.1016/j.amepre.2004.12.006

Nelson, M., Neumark-Stzainer, D., Hannan, P., Sirard, J., \& Story, M. (2006) Longitudinal and secular trends in physical activity and sedentary behavior during adolescence. Pediatrics, 118, 1627-1634. DOI: 10.1542/peds.20060926

Olds, T., Ferrar, K., Gomersall, S., Maher, C., \& Walters, J. (2012). The elasticity of time: Associations between physical activity and use of time in adolescents. Health Education \& Behavior, 39(6), 732-735. DOI: 10.1177/ 1090198111429822

Olds, T., Ridley, K., \& Dollman, J.(2006). Screenieboppers and extreme screenies: The place of screen time in the time budgets of 10-13 year-old australian children. Australian and New Zealand Journal of Public Health, 30(2), 137142. DOI: 10.1111/j.1467-842X.2006.tb00106.X

Olds, T., Wake, M., Patton, G., Ridley, K., Waters, E., Williams, J., \& Hesketh, K. (2009). How do school-day activity patterns differ with age and gender across adolescence? Journal of Adolescent Health, 44(1), 64-72. DOI: 10.1016/ j.jadohealth.2008.05.003

Olshansky, S., Passaro, D., Hershow, R., Layden, J., Carnes, B., Brody, J., .. Ludwig, D. (2005). A potential decline in life expectancy in the United States in the 21st century. New England Journal of Medicine, 352, 1138-1145. DOI 10.1056/NEJMsr043743

Owen, N., Leslie, E., Salmon, J., \& Fotheringham, M. (2000). Environmental determinants of physical activity and sedentary behavior. Exercise and Sport Sciences Reviews, 28, 153-158.

Pardee, P., Norman, G., Lustig, R., Preud’homme, D., \& Schwimmer, J. (2007). Television viewing and hypertension in obese children. American Journal Preventive Medicine, 33, 502-5044. DOI: 10.1016/j.amepre.2007.07.036

Pearson, N., Atkin, A., Biddle, S., Gorely, T., \& Edwardson, C. (2009). Patters of adolescent physical activity and dietary behaviours. International Journal of Behavioral Nutricion and Physical Activity, 6(1), 45. DOI: 10.1186/14795868-6-45

Plano Tecnologico da Educação(s/d). Resolução do Conselho de Ministros n. ${ }^{\circ} 137 /$ 2007, de

18de Setembro 2007. Retrieved from http://www.pte.gov.pt/pte/PT/OPTE/index.htm

Ponte, C. (2011). Acessos e literacias digitais: Resultados portugueses do inquérito europeu EU Kids Online. CIMJ, Faculdade de Ciências Sociais e Humanas, Universidade Nova de Lisboa in Sara Pereira(Org.) (2011) Congresso Nacional «Literacia, Media e Cidadania» 25-26 Março 2011, Braga, Universidade do Minho: Centro de Estudos de Comunicação e Sociedade. ISBN 978-98997244-1-9.

Pombeiro, M. (2015). Estilos de Vida dos Jovens: Tempo de Ecrã e Atividade Física. (Tese de Doutoramento não publicada). Lisboa: FMH-UL.

Rideout, V., Foehr, U., \& Roberts, D. (2010). Generation M2: Media in the lives of 8-to18-year-olds. Menlo Park, California: Kaiser Family Foundation.

Salmon, J., Telford, A., \& Crawford, D. (2004). The Children's Leisure Activities Study (CLASS): summary report. Melbourne, Australia. Centre for physical activity and nutrition research: Deakin University.
Salmon, J., Tremblay, M., Marshall, S., \& Hume, C. (2011). Health risks, correlates, and interventions to reduce sedentary behavior in young people. American Journal of Preventive Medicine, 41, 197-206. DOI: 10.1016/ j.amepre.2011.05.001

Sandercock, G, Ogunleye, A., \& Voss, C. (2012). Screen time and physical activity in youth: Thief of time or lifestyle choice? Journal of Physical Activity and Health, 9, 977-984.

Schoeppe, S., Duncan, M., Badland, H., Oliver, M., \& Curtis, C. (2013).Associations of children's independent mobility and active travel with physical activity, sedentary behaviour and weight status: Asystematic review. Journal of Science and Medicine in Sport, 16, 312-319. DOI: 10.1016/j.jsams.2012.11.001

Sedentary Behaviour and Obesity Expert Working Group(2010). Sedentary behaviour and obesity: Review of the current scientifýc evidence. London: Department of Health.

Sharif, I., \& Sargent, J. (2006). Association between television, movie, and video game exposure and school performance. Pediatries, 118(4), 1061-1070. DOI: 10.1542/peds.2005-2854

Sisson, S., Broyles, S., Baker, B., \& Katzmarzyk, P. (2010). Screen time, physical activity and overweight in U.S. youth: National survey of children's health. Journal of Adolescent Health, 47, 309-311.

Sundblad, G., Jansson, A., Saartok, T., Renstrom, P., \& Engstrom, L. (2008). Selfrated pain and perceived health in relation to stress and physical activity among school-students: A 3 year follow-up. Pain, 136(3), 239-249. DOI: 10.1016/ j.pain.2007.06.032

Telama, R. (2009). Tracking of physical activity from childhood to adulthood: A review. Obesity Facts 3. DOI: 10.1016/j.amepre.2004.12.003

Troiano, R., Berrigan, D., Dodd, K., Mâsse, L., Tilert, T., \& McDowell, M. (2008). Physical activity in the United States measured by accelerometer. Medicine and Science in Sports and Exercise, 40(1), 181-188. DOI: 10.1249/ mss.0b013e31815a51b3

U.S. Department of Health and Human Services (USDHHS) (2008). Physical activity guidelines for adults. Centers for Disease Control and Prevention. Division of Nutrition, Physical Activity and Obesity.

Utter, J., Denny, S., Robinson, E., Ameratunga, S., \& Milfont, T. (2011). Social and physical contexts of schools and neighborhoods:Associations with physical activity among young people in New Zealand. American Journal of Public Health, 101(9), 1690-1695. DOI: 10.2105/AJPH.TEST.2011.300171

Verloigne, M., Van, L., Maes, L., \& Brug, J. (2012). Family- and school-based correlates of energy balance-related behaviours in 10-12-year-old children: A systematic review within the ENERGY (European Energy balance Research to prevent excessive weight Gain among Youth) project. Public Health Nutrition, 15, 1380-1395. DOI: 10.1017/S1368980011003168

Walters, S., Barr-Anderson, D., Wall, M., \& Neumark-Sztainer, D. (2009). Does participation in organized sports predict future physical activity for adolescents from diverse economic backgrounds? Journal of Adolescent Health, 44, 268 274. DOI: 10.1016/j.jadohealth.2008.08.011

White, P., \& McTeer, W. (2012). Socioeconomic status and sport participation at different developmental stages during childhood and youth: Multivariate analyses using canadian national survey sata. Sociology of Sport Journal, 29, 186-209.

Withers, K., \& Sheldon, R. (2008). Behindthe screen, the hidden life of younth online. London: Institute for Public Policy Research.

Wong, S., Halaki, M., \& Chow, C. (2013). The effects of moderate to vigorous aerobic exercise on the sleep need of sedentary young adults. Journal of Sports Sciences, 31(4), 381-386. DOI: 10.1080/02640414.2012.733823

World Health Organization (WHO) (2006). Promoting physical activity for health - a framework for action in the WHO European region. Steps towards a more physically active Europe. Copenhagen: WHO.

Word Health Organization (WHO) (2008). Inequalities in young people's health HBSC international report from the 2005\&2006 survey. Copenhagen: WHO.

World Health Organization(WHO)(2009). A snapshot of the health of young people in Europe. Brusels: WHO.

World Health Organization (WHO)(2012). Global strategy on diet, physical activity and health. Retrieved from http://www.who.int/dietphysicalactivity/ childhood_why/en/index.html

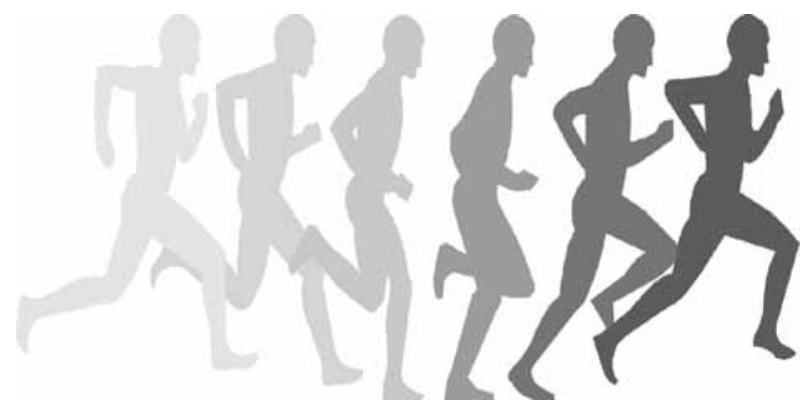

